\title{
FORTY YEARS OF MASS-BALANCE OBSERVATIONS ON GLACIER DE SARENNES, FRENCH ALPS
}

\author{
by
}

François Valla

(Division Nivologie, CEMAGREF, B.P. 76, 38402 Saint-Martin-d'Hères Cedex, France)

\section{ABSTRACT}

Located south of Grenoble, in the French Alps, Glacier de Sarennes is a small cirque glacier whose mass balance has been measured since 1948 .

Field measurements are made after the accumulation period (from October to May) and during the ablation period (from June to September). The main variables for snow are depth, density, and water equivalent for accumulation, together with ice depth and water equivalent for ablation which are used to calculate mass balance and regime. We present an example of the data collected on the glacier during the 1986-87 season, the evolution of the mass balance during the summer of 1987 , and the main variables followed during the 40 years of observation, 1948-88. Mass balance, accumulation, and ablation are directly related to precipitation and temperature. Glacier de Sarennes is a simple glacier which has no tongue and no ice movement, and is like a gigantic rain gauge. The evolution of its mass balance is simply related to the meteorological variables of the year. For more significant and complex glaciers, it is necessary to take account of past as well as present meteorological variables.

\section{INTRODUCTION}

French scientists have been interested in Glacier de Sarennes for a long time. As long ago as 1891, the wellknown Prince Roland Bonaparte observed the stationary front of the glacier and marked its position. Fifteen years later (1905-06), Flusin, Jacob, and Offner mapped the glacier at a scale of $1: 10000$ and also reported their observations (Cherrey, 1950). The Department of Water and Forests (Eaux et Forêts), and the Technical Centre of Agriculture (CT.GREF, and now CEMAGREF) have studied the glacier since 1921 by occasional photographic and topographic surveys, and since 1948 by detailed and frequent mass-balance measurements.

\section{LOCATION OF GLACIER DE SARENNES}

Glacier de Sarennes is a small cirque glacier located in the Grandes Rousses range, $30 \mathrm{~km}$ east-south-east of Grenoble, at the northern border of the French Oisans Massif and with coordinates $45^{\circ} 10^{\prime} \mathrm{N}, 6^{\circ} 10^{\prime} \mathrm{E}$. It covers an area of about $0.82 \mathrm{~km}^{3}$ between 3200 and $2800 \mathrm{~m}$ a.s.l. Today, access from the top of Pic du Lac Blanc $(3327 \mathrm{~m})$ is very easy, using the highest cableway of the ski area known as L'Alpe d'Huez (Péguy, 1962).

\section{THE GLACIER MODEL}

In order to have a realistic representation of Glacier de Sarennes, we use a simple model calculated with values from five selected points, judged to be representative with respect to altitude and exposure (Fig. 1). At a date, $d$, mass balance, $M$, is measured at five stakes, and the mean value calculated from the following area-weighted sum

$$
M(d)=0.05 X_{1}+0.10 X_{2}+0.25 X_{3}+0.25 X_{4}+0.35 X_{5}
$$

where the coefficients are the percentage of glacier area represented by each stake and $X_{1}-X_{5}$ are the balances measured at stakes $1-5$ (Valla, 1984).

\section{DATA COLLECTION}

During normal years, there is snow accumulation between the 8 months from October to May and ablation in the following 4 months from June to September. The glacier is not visited during winter to obtain measurements of the variation in the amount of snow; the first datum collection is that of maximum accumulation and this is made around 1 June, after which measurements are made every 3 weeks up to the collection date of around 30 September of ablation data. Sunny autumns are the exception and in them we are obliged to continue measurements until the end of the ablation period, which was until 10 November in 1985 . At the five stakes, snow accumulation in metres of water

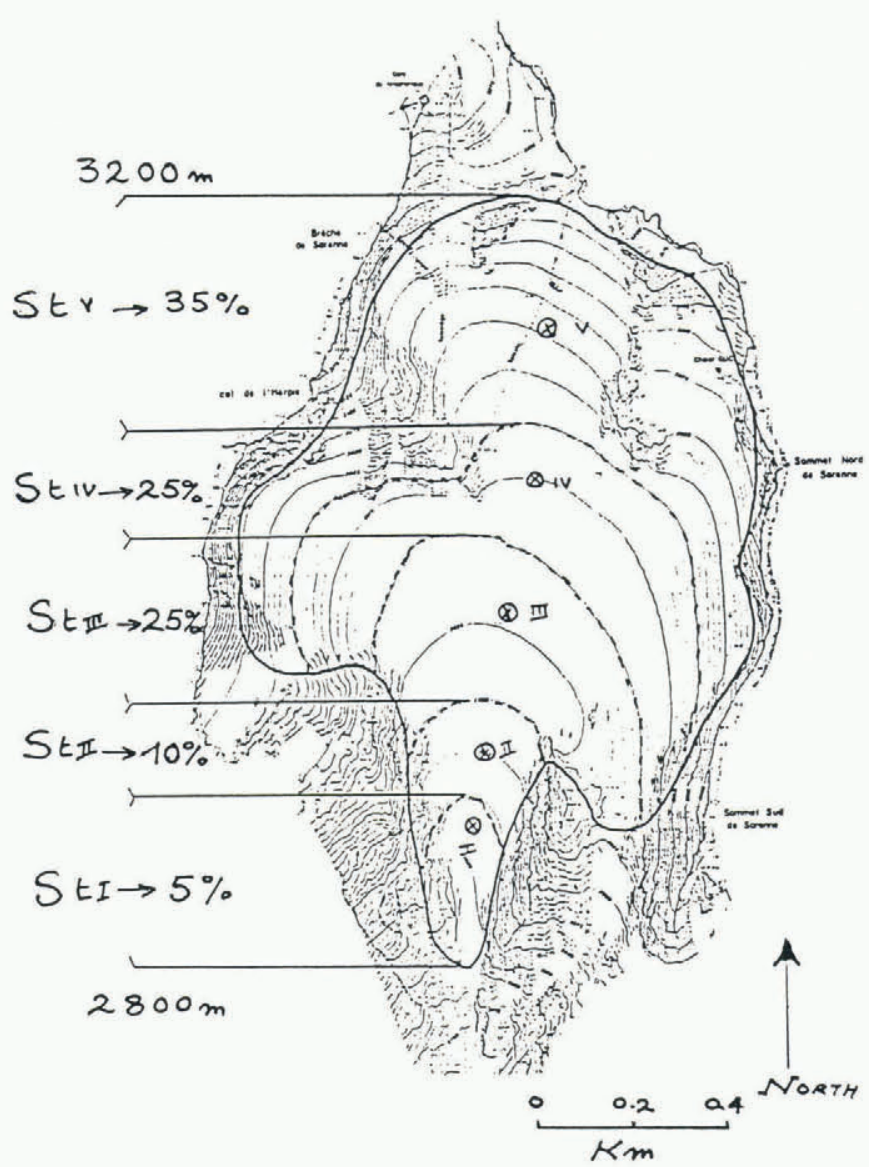

Fig. 1. Characteristics of Glacier de Sarennes. 


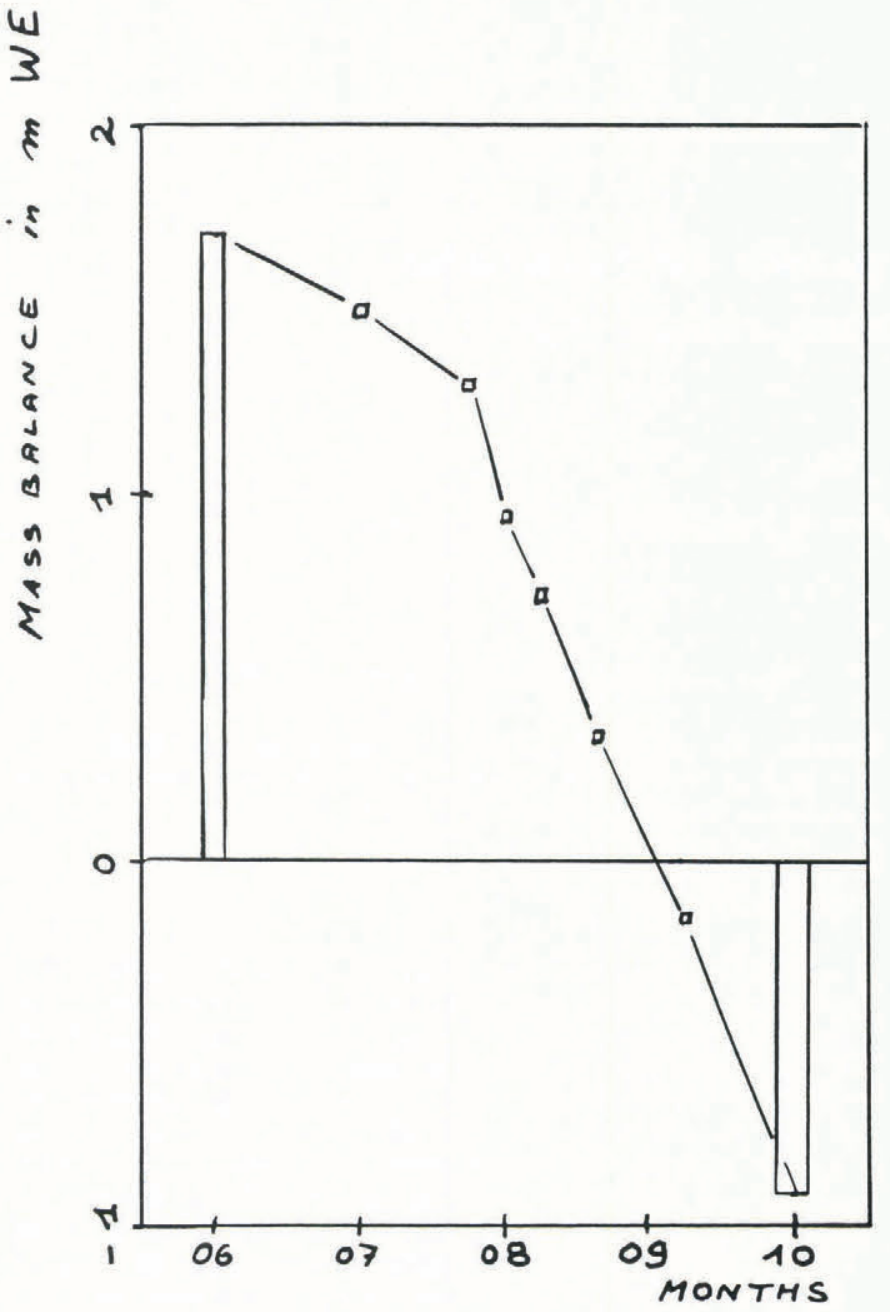

Fig. 2. Seasonal evolution (1986-87) of mass balance on Glacier de Sarennes. Early June accumulation $=1.72 \mathrm{~m}$ w.e. ablation is moderate in June and July, stronger in August and September with an exceptional ablation rate of $1 \mathrm{~m}$ w.e. $/$ month. Total ablation $=2.64 \mathrm{~m}$ w.e., final mass balance in early October $=0.92 \mathrm{~m}$ w.e.

equivalent is measured by weighing a snow core (with the CEMAGREF snow-core sampler), and ablation of ice is measured by emergence of pre-placed ice stakes. Local mass balance is deduced from the above data and the Glacier de Sarennes mass balance is calculated using the formula for $M(d)$ given above.

\section{SEASONAL EVOLUTION OF THE GLACIER}

The data collected at each stake include height of snow, weight of the core sample, and variation of ice level after the snow cover has melted away. At any date, using a simple calculation, we can determine the accumulation, ablation, mass balance, and ablation rate.

TABLE I. CHARACTERISTICS OF 1986-87 YEAR IN TERMS OF METRES OF WATER AND RANK RELATIVE TO FORMER YEARS

(Mass balance $=$ accumulation - ablation;

Regime $=$ accumulation + ablation $)$

$\begin{array}{lrrrrr}\begin{array}{l}\text { Water } \\ \text { source }\end{array} & \text { Water } & \text { Rank } & \text { Mean } & \begin{array}{c}\text { Standard } \\ \text { deviation }\end{array} & \begin{array}{r}\text { Mean } \\ \text { deviation }\end{array} \\ \text { Accumulation } & 1.72 & 17 \text { th } & 1.62 & 0.58 & 0.10 \\ \text { Ablation } & 2.64 & 9 \text { th } & 2.16 & 0.72 & 0.48 \\ \text { Mass balance } & -0.92 & 11 \text { th } & -0.54 & 0.86 & -0.38 \\ \text { Regime } & 4.36 & 12 \text { th } & 3.76 & 1.00 & 0.60\end{array}$

Figure 2 shows the 1986-87 seasonal evolution of the mass balance for Glacier de Sarennes as an example. Table I gives the characteristic values for the same hydrological year.

\section{EVOLUTION OF MASS BALANCE, 1948-88}

Table II is the result of 40 years of observations on Glacier de Sarennes. Figure 3 shows variations in accumulation, ablation, mass balance, and regime between 1948 and 1988. The main observations are.

\section{Accumulation}

The extremes are $0.33 \mathrm{~m}$ of water equivalent in $1975-76$, and $2.85 \mathrm{~m}$ in $1982-83$. There is no clear trend, but there are periods such as that between 1976 and 1988 with continuously high values which are correlated with the heavy level of precipitation.

\section{Ablation}

The extremes are more widely separated than are those for accumulation, with $0.79 \mathrm{~m}$ during the summer of 1968 and $3.70 \mathrm{~m}$ in 1949, compared with $3.68 \mathrm{~m}$ in 1986. No steady pattern emerges except that since 1982 there has been continuously high ablation.

\section{GLACIER de SARENNE_GRANDES ROUSSES _ FRANCE}
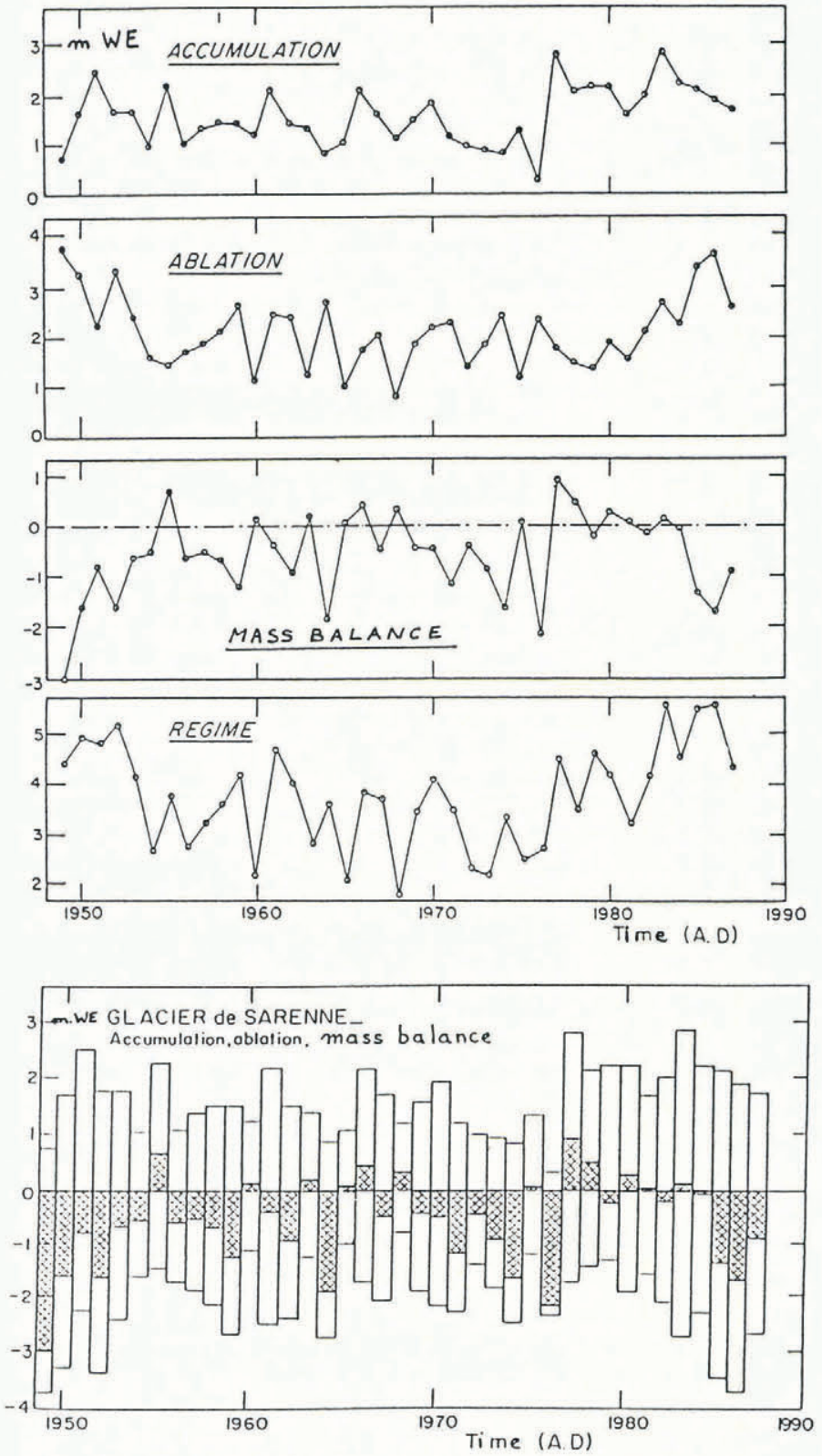

Fig. 3. Evolution of accumulation, ablation, mass balance, and regime on Glacier de Sarennes, 1948-88, in m w.e.. Note trend of high values for years 1977-87. 
TABLE II. 40 YEARS OF DATA ON GLACIER DE SARENNES (1948-88). NUMBERS ARE METRES OF WATER EQUIVALENT

\begin{tabular}{rrrrrr} 
Cycle & \multicolumn{1}{c}{ Year } & Accumulation & Ablation & Mass balance & Regime \\
1 & & & & & \\
2 & $1948-49$ & 0.71 & 3.70 & -2.99 & 4.41 \\
& $49-50$ & 1.68 & 3.30 & -1.62 & 4.98 \\
3 & & & & & \\
4 & $1950-51$ & 2.50 & 2.30 & +0.20 & 4.80 \\
5 & $51-52$ & 1.75 & 3.37 & -1.62 & 5.12 \\
6 & $52-53$ & 1.77 & 2.41 & -0.64 & 4.18 \\
7 & $53-54$ & 1.05 & 1.60 & -0.55 & 2.65 \\
8 & $54-55$ & 2.20 & 1.54 & +0.66 & 3.74 \\
9 & $55-56$ & 1.08 & 1.68 & -0.60 & 2.76 \\
10 & $56-57$ & 1.38 & 1.90 & -0.52 & 3.28 \\
11 & $57-58$ & 1.47 & 2.14 & -0.67 & 3.61 \\
12 & $58-59$ & 1.43 & 2.69 & -1.26 & 4.12 \\
& $59-60$ & 1.20 & 1.08 & +0.12 & 2.28 \\
13 & $1960-61$ & & & & \\
14 & $61-62$ & 2.15 & 2.54 & -0.39 & 4.69 \\
15 & $62-63$ & 1.55 & 2.46 & -0.91 & 4.02 \\
16 & $63-64$ & 1.45 & 1.26 & +0.19 & 2.72 \\
17 & $64-65$ & 0.89 & 2.72 & -1.82 & 3.61 \\
18 & $65-66$ & 1.03 & 1.00 & +0.03 & 2.03 \\
19 & $66-67$ & 2.14 & 1.72 & +0.42 & 3.86 \\
20 & $67-68$ & 1.63 & 2.04 & -0.41 & 3.67 \\
21 & $68-69$ & 1.13 & 0.79 & +0.34 & 1.92 \\
22 & $69-70$ & 1.59 & 1.95 & -0.36 & 3.54 \\
& & 1.82 & 2.23 & -0.51 & 4.05 \\
23 & $1970-71$ & 1.22 & 2.32 & -1.10 & 3.54 \\
24 & $71-72$ & 1.01 & 1.38 & -0.37 & 2.39 \\
25 & $72-73$ & 0.95 & 1.82 & -0.87 & 2.27 \\
26 & $73-74$ & 0.88 & 2.48 & -1.60 & 3.36 \\
27 & $74-75$ & 1.32 & 1.21 & +0.11 & 2.53 \\
28 & $75-76$ & 0.33 & 2.40 & -2.07 & 2.73 \\
29 & $76-77$ & 2.78 & 1.79 & +0.99 & 4.57 \\
30 & $77-78$ & 2.07 & 1.52 & +0.55 & 3.59 \\
31 & $78-79$ & 2.26 & 2.37 & -0.11 & 4.63 \\
32 & $79-80$ & 2.25 & 1.93 & +0.32 & 4.18 \\
& & & & & \\
33 & $1980-81$ & 1.65 & 1.61 & +0.04 & 3.26 \\
34 & $81-82$ & 2.03 & 2.13 & -0.10 & 4.16 \\
35 & $82-83$ & 2.85 & 2.75 & +0.10 & 5.60 \\
36 & $83-84$ & 2.23 & 2.29 & -0.06 & 4.52 \\
37 & $84-85$ & 2.07 & 3.44 & -1.37 & 5.57 \\
38 & $85-86$ & 1.89 & 3.68 & -1.79 & 5.57 \\
39 & $86-87$ & 1.72 & 2.64 & -0.92 & 4.36 \\
40 & $87-88$ & 2.20 & 2.89 & -0.69 & 5.09
\end{tabular}

\section{Mass balance}

Extremes range from $+0.99 \mathrm{~m}$ in 1977 to $-2.99 \mathrm{~m}$ in 1949. It is probable that higher values than these were reached during the period from 1940 to 1950 . Between 1971 and 1976, mass balances were negative. We notice positive balances from 1965 to 1970, and again more recently from 1977 to 1984 . With a mean of $-0.54 \mathrm{~m}$, Glacier de Sarennes is losing $0.60 \mathrm{~m}$ of ice each year, which means that after 40 years the ice level is $24 \mathrm{~m}$ lower than it was when observations began.

\section{Regime}

The total amount of water in transit in the glacier has a smaller range of values than the other variables. The minimum run-out is $1.92 \mathrm{~m}$ in $1967-68$, and the maximum is $5.60 \mathrm{~m}$ in $1982-83$, with $5.57 \mathrm{~m}$ in $1985-86$ and $5.51 \mathrm{~m}$ in 1984-85. No steady variation is noted but, as for ablation, continuously high values have been recorded.

\section{A GIGANTIC RAIN GAUGE}

Because of its lack of movement, Glacier de Sarennes can be considered as a rain gauge with an area of about $1 \mathrm{~km}^{2}$. All precipitation is trapped and it is easy to measure the evolution of the mass balance. Accumulation is controlled by the amount of precipitation between the months of October and May. Ablation is regulated by the temperature during the 4 months of summer, from June to
September, with higher weight being given to the July and August values than to those of other months (de Crécy, 1963; Bienvenu, 1981). Using a mathematical model, together with meteorological data from Lyon, $130 \mathrm{~km}$ west of the glacier, Martin (1977) has been able to reconstruct the mass-balance curve for Glacier de Sarennes since 1882.

\section{GLACIER FLUCTUATIONS IN THE ALPS}

Reynaud (1980) proposed an extension of the linear balance model of Lliboutry (1974) for the whole of the Alps. Using the long Glacier de Sarennes mass-balance series together with other data, he showed that the mass budgets for all Alpine glaciers can be correlated (Reynaud and others, 1986). Simple glaciers like Glacier de Sarennes react immediately to climatic forcing, but for morphologically complex glaciers, like Mer de Glace in the Mont Blanc range, the reaction is the response to a combination of all the previous pressures but, despite this, it is still possible to have an accurate picture of the annual fluctuation. This is of greatest interest when the tongue of a glacier is in a region of human activity.

\section{OUTLOOK}

Glacier de Sarennes, together with Storglaciären in Sweden, has one of the longest monitoring records of all 
glaciers. For both, data collection began just after World War II. This uninterrupted series of data is of real value and should be continued. This small cirque glacier reacts immediately to climatic pressures, and one of our next goals is to compute a new model using meteorological variables from Grenoble.

\section{ACKNOWLEDGEMENTS}

We thank all the people who helped to collect data, especially M. Cherrey, M. Garavel, M. de Crécy, the students who spent nights in our small cabin on the glacier side, and the scientists interested in our work, especially Drs L. Reynaud and S. Martin. Finally, we thank CEMAGREF, the research organization of the French Ministry of Agriculture, for supporting this field work from 1948.

\section{REFERENCES}

Bienvenu, T. Unpublished. Analyse de la série de bilan de masse relevée sur le glacier de Sarennes de 1949 à 1980 et la corrélation de ces bilans avec les facteurs météorologiques. (Master's thesis, Université de Grenoble, 1981.)
Cherrey, M. 1950. Glacier de Sarennes; études de glaciologie de 1949. Houille Blanche, Special issue à 1950.

Crécy, L. 1963. Le Glacier de Sarennes et le climat grenoblois. Ann. de l'ENGREF, 20(3), 344-370

Lliboutry, L. 1974. Multivariate statistical analysis of glacier annual balances. J. Glaciol., 13(69), 371-392.

Martin, S. 1978. Analyse et reconstitution de la série des bilans annuels du glacier de Sarennes, sa relation avec les fluctuations du niveau de trois galciers du Massif du Mont Blanc (Bosson, Argentières et Mer de Glace). Z . Gletscherk. Glazialgeol., 13(1-2), 1977, 127-153.

Péguy, C.P. 1962. Observations glaciologiques dans le massif des Grandes Rousses (France). Biul. Peryglac., 11, 279-286.

Reynaud, L. 1980. Can the linear balance model be extended to the whole Alps? International Association of Hydrological Sciences Publication 126 (Workshop at Riederelp 1978 - World Glacier Inventory), 273-284.

Reynaud, L., M. Vallon, and A. Letréguilly. 1986. Massbalance measurements: problems and two new methods of determining variations. J. Glaciol., 32(112), 446-454.

Valla, F. 1984. Bilan du glacier de Sarennes en 1982-83, 35ème année d'observation. Houille Blanche, 6-7, 526-528. 